\title{
8 \\ Female Domestic Workers on the Move: Examining Global Householding and Global De-Householding in Today's World
}

\author{
Rieko Karatani
}

\subsection{Introduction}

Blown in by a windstorm from the East, Mary Poppins came to the Banks' home at Number 17 Cherry Tree Lane, London. The main character of P. L. Travers' children's novel, published in 1934, is allegedly the world's best-known "nanny." ${ }^{1}$ The Banks' household is a traditional one. Mr Banks works in a bank in the City of London, leaving the task of hiring a suitable nanny for their children to Mrs Banks alone. Mrs Banks places a job advertisement in the newspaper, specifying a strong letter of recommendation as a requirement. Thus, a female employer decides the employment conditions of and negotiates with the female employee-a woman directing another woman. ${ }^{2}$ In the Banks' home, the nanny is to work in a live-in environment, sleep in a nursery room, and have one day off every other Thursday. Even then, of course, it is not a full day, but only the afternoon between 1:00 p.m. and 6:00 p.m. In the eyes of the nanny's employer, there exists neither labor standard legislation nor any basic rights for laborers or employees.

The International Labour Organization (ILO) estimates that today there are up to 100 million Mary Poppinses around the world. It claims that these women are forced to bear even tougher conditions than the main character of Travers' children's novel. ${ }^{3}$ It is an airplane, not an east wind, that brings them to developed countries, such as Britain, from developing countries such as the Philippines. They arrive in high numbers to look after families in host countries, leaving their own families behind. Female overseas workers are also increasingly participating in other sectors traditionally considered to be "women's work," such 
as health care and nursing for the sick and elderly (Ehrenreich \& Hochschild, 2002; Kingma, 2006). Their basic rights, including days off each week, set hours, and minimum wage, have often been ignored, as if they have been forced into modern-day slavery.

This chapter analyzes the situation of today's Mary Poppinses in developed countries and beyond from an international relations scholarship perspective. In doing so, it focuses on the household as the basic unit of social reproduction, and aims to reveal the causes and effects of its reconfiguration beyond national borders. The conditions of female migrant workers are by no means simply a deal between a powerful and a not-so powerful woman. Rather, both women form part of a rapidly growing phenomenon described as "global householding." ${ }^{4}$ Such a phenomenon is not confined to one region, but is prevalent all over the world. Asia is certainly not immune from it.

This chapter concentrates on three tasks. First, by examining the "security" and "insecurity" of female overseas domestic workers (FODWs), it aims to incorporate the perspectives of both "gender" 6 and migration studies into the discipline of security studies. Within the study of International Relations (IR), security studies have traditionally focused on the military concerns of states. Recently, towards and since the end of the Cold War, security studies has undergone enormous changes, its scope of study being greatly expanded to cover non-military dimensions of security (Buzan, 1991). The field may nonetheless still lack analytical frameworks that integrate these wider issues into a holistic notion of security. "Global householding" is a vastly understudied, if not completely ignored, subject within security studies, despite involving an increasing number of countries and affecting so many people's lives both in positive and negative ways.

Second, this chapter attempts to explain how constraining regimes are in fact currently constructed in a multi-layered form, subsequently strengthening the "insecurity" of FODWs. It then demonstrates that these multi-layered regimes at national, regional, and global levels, whether upheld in practice or circumvented, have become a constitutive part of this "global householding" phenomenon. "Insecurity" for FODWs stemming from legal restrictions is found not only at a national level, but also within additional layers of regional and global jurisdiction. Scholars in gender and migration studies have examined the legal as well as psychological elements of the insecurities of women, especially female migrants, who accept live-in domestic jobs and are forced to work long hours under tough working conditions. ${ }^{7}$ IR scholarship can further show 
that the processes of "global householding" are increasingly occurring all over the world, and these women are subject to the multiplicity of the constraining national, regional, and global regimes.

Third, this chapter tries to challenge the state-centric academic analysis, and concentrates instead on the household as the space where individuals of different backgrounds meet and pool diverse resources for the purpose of ensuring the continuity of the collective unit. Within the household, we communicate and negotiate daily with one another, with efforts to establish what this volume calls the interactive "multiculturality," on which the basis of the convivial relationship is formed. By demonstrating that households are undergoing transformation due to population movements (one of the main forms being labor migrations), this chapter highlights how our differences are currently confronted and overcome through our daily contacts and interactions. Specifically, this analysis demonstrates that "global householding" has become a prevalent livelihood strategy in both developed and developing countries. Mary Poppinses are no longer localized characters in one region, but have been globalized and regulated. While such workers might help to secure access to the world for those who can afford to hire them, this process also makes the workers themselves and their families become even more insecure. By underestimating the impact of "global householding," either localized or temporary, we risk missing the "actually existing" struggles caused by global population movement and transactions.

The next section explains the causes of the widespread "feminization" of migration and introduces the concepts of "global householding" and "global de-householding." The chapter then examines how the disciplines of international relations and security studies deal with the "security" and "insecurity" of FODWs. To explore the "security" and "insecurity" of FODWs, this chapter draws on gender studies by adopting the analytical framework of the so-called "gendered geographies of power" (Pessar \& Mahler, 2003, pp. 812-846), a research concept focusing on the ability of each female individual to act as an agent in today's world. It questions the extent to which each female individual is capable of acting as a potential agent, i.e. what determines their agency and what influences their ability to fulfill their power as an agent? This leads to the following section, which focuses on the way national, regional, and global regimes do indeed constrain such agency and thereby threaten the "security" of FODWs.

In conclusion, this chapter argues that whenever mothers or daughters go abroad as FODWs, their family members back home are exposed 
to "insecurity," most likely to a similar degree as the FODWs themselves. Possibly some FODWs in host countries become empowered, (re-)gaining an agency they never possessed in their home nation. Nonetheless, the "insecurity" of the family back home can only be overcome through substantial changes in the "geographies of power" in both the host and home countries. With both FODWs and their families in sight, this chapter suggests in its final analysis that we cannot conclude that the emerging activities of FODWs represent a great sign of "insecurity reduction" if one thereby ignores the inherently double-sided dimension of the problem. It also emphasizes that the nexus of global householding and global de-householding affects our lives in today's globalized world, and no one, whether in Europe, Africa, or Asia, can be free from the changes-and even crises-caused by the reconfiguration of the household beyond national borders. Thus, we are hard-pressed to find a new framework in which to analyze this global phenomenon.

\subsection{The "feminization" of international migration}

\subsubsection{The "feminization" of international migration explained}

For Castles and Miller (2009), "feminization" is one of six key words describing the international movement of people since the 1980s. ${ }^{8}$ It is true that women have been moving abroad for as long as their male counterparts. However, these two scholars emphasize the increasing volume of female migration since the 1980s as remarkable. Structural changes in the industry sector and more active female participation in the labor market, as well as new demands from aging populations in developed countries, have made overseas female workers an increasingly indispensable workforce in the care and homemaking fields (Pessar \& Mahler, 2003). These fields are traditionally defined as "women's work." They tend to pay very little and involve hiring temporary or even irregular workers. A large percentage of overseas female workers are employed in live-in situations. Altogether, their unique plights-being underpaid, insecure, dependent, and isolated-have received little academic attention so far. ${ }^{9}$

Numerous studies have already revealed the reasons for the increasing number of female overseas workers (Gregson \& Lowe, 1994; Enloe, 2000, pp. 177-194). Building on such scholarship, this chapter emphasizes that the social and economic conditions of the sending countries contribute to the trend as much as those at the receiving end. Two contributing factors are the introduction of structural adjustment policies (SAPs) in the 1990s and the existing "domestic servant culture" among middle-class 
families in many less developed countries. Generally, welfare spending has been reduced to meet the targets set by SAPs. Thus, the poor become poorer and their standard of living plummets. ${ }^{10}$ Foreign companies in export promotion zones tend to create high demand for young female workers, but lower demand for their male counterparts. Once young women then enter the waged labor market, they naturally aim for higher wages, whether the jobs they seek are offered domestically or abroad. As long as they are well paid, they might not hesitate to venture overseas and send more money back home. Without public welfare support, it is they who need to fend for their aging parents and young siblings.

In addition, it has long been quite common in the developing world to hire home servants. As such, a so-called "domestic servant culture" has prevailed for some time. It is often the case that FODWs had already worked as domestic servants in their own countries when they took the step of going abroad (Connell, 2008). While working as a servant in a middle-class family in their home countries, many FODWs at the same time allot a portion of their income to employing a servant to look after their own family. Hence, an economic "food chain of domestic work" emerges. At all levels of the chain, people become accustomed to relying on outside helpers in their own houses, whether they actually like it or not. With family care in the hands of waged servants, it is the drive for the highest wage, be it in the home country or in a foreign land, that entices them to work abroad. At the upper end of the chain, wealthy families in the developed world successfully obtain low-waged domestic workers by extending their hunt globally. In so doing, they may raise their standard of living, resulting in more time and money for themselves. To support the high standard of those now rich in time and cash, the FODWs, in contrast, suffer global separation from their own loved and treasured families.

\subsection{2 "Global householding" and "Global de-householding"}

In this chapter, the key concepts used to analyze female migration are "global householding" and "global de-householding." The concept of "global householding" was developed by Michael Douglass of Hawaii University and his present research group (Douglass, 2006). With increasing global movements of people, he renews his focus on the concept of "household." The importance of "household" in the world-system was emphasized by Immanuel Wallerstein more than two decades ago (Smith, Wallerstein, \& Evers, 1984). According to Douglass, today's "household" is undergoing enormous changes due to low fertility rates and the longevity prevalent throughout the developed world. 
In addition, governments worldwide have increasingly privatized social services, and thus providing care for the elderly and infants has become too great a burden for each household to bear on its own. With the population rapidly aging and shrinking, the households of developed countries are seeking help from abroad, mostly from developing countries. As a result, quite a few "households" in this globalized world are supported by financial and physical inputs beyond national borders, and are thereby successively transformed into "global households," or rather forms of "global householding" (Douglass, 2006, pp. 421-425). Douglass summarizes the major features of "global householding" as the increasing attempts to form and sustain households through global movements and transactions among household members through various means such as marriage, child-bearing and adoption, and hiring foreign domestic helpers and caregivers (Douglass, 2006, pp. 424-425).

To supplement this idea, this chapter introduces an additional dimension to "global householding," namely "global de-householding." By hiring FODWs, an employer's family indeed experiences "global householding." It clearly improves their quality of life by having FODWs do the cooking and cleaning, for example. At the same time, however, the FODWs' own families back home face "global de-householding," losing an important family member who could have looked after them and improved their quality of life as well. In a sense, one of the most important features of today's "insecurity" of FODWs is that it is by nature globalized beyond national jurisdiction. The conditions for both concepts, "global householding" and "global de-householding," occur simultaneously and are inseparably interlinked. Furthermore, whether it is regarded as "global householding" or "global de-householding" depends on whose viewpoint we assume and the extent to which we see ourselves as autonomous agents in the process.

"Global householding" and "global de-householding" are relational concepts in that they involve the countries and family units at both the sending and receiving ends. The extent of their effects depends on the relationship between those who move across and those who stay within national borders. As pointed out, it has long been common for upper class families in developed Western European countries to hire live-in maids. The same can be said for the wealthy in developing countries. In developing countries, such live-in maids were also often alienated and exposed to long working hours under tough conditions. Today's Mary Poppinses, nonetheless, are mainly from developing countries, leaving their families behind to work long and hard in the rich world. Thanks to FODWs, those who live in developed countries may be freed to 
concentrate their energies on waged jobs and enjoy more leisure time. Thanks to "global householding," they can choose what to do and what not to do. Furthermore, some may actively further advance "global householding" by sending their own children to study or work abroad in the quest for higher wages. Ultimately, they choose whether or not to expose themselves to the "global householding" phenomenon. In contrast, most FODWs venture abroad toward something they cannot gain in their home countries, such as economic advancement, or social or political freedom.

From the viewpoint of FODWs coming from the Philippines, for example, the "global householding" of their employer in Britain is based on their own "global de-householding." Under these circumstances, such Filipinas are deprived of the choice of caring for their aging parents and growing children. Some academics are concerned that the children of FODWs may suffer psychological loss, thus falling into "insecurity" in return for the economic gains accrued (Parreñas, 2005). Essentially, the "global householding" of families in developed countries always exists against the background and mostly at the expense of the "global de-householding" of those in less affluent countries. Moreover, as pointed out earlier, FODWs are denied the opportunity to act as independent actors with the ability to claim their own rights and their own "security" in host countries. Consequently, the actual costs of upholding a high level of "security" for those families who opt for "global householding" are simply transferred, in the form of "global de-householding," to the FODWs and the families they leave behind. These two concepts should therefore be examined together to demonstrate that these developments are two sides of the same coin. When viewed as a pair, they present a complete picture of the rewards and penalties arising from these global phenomena.

\subsection{The "security" and "insecurity" of FODWs}

\subsubsection{What do we mean by the "security" and "insecurity" of FODWs?}

Since the UNDP Human Development Report was published in 1994, its key concept, "human security," has inspired a heated debate among scholars and practitioners. Numerous studies have attempted to clarify the relationship between "human security" and the conventional understanding of "national security" in IR. Some scholars argue that the newly suggested concept of "human security" could be further differentiated to distinguish between "human security," which is provided 
by societal institutions and services, and "personal security," which comprises the maintenance of life and existence (Hatsuse, 2003). With regard to FODWs, the immigration legislation and policies of the receiving country often assume their dependency on the male member of the family, simply ignoring the fact that the FODWs travel independently to work and support themselves. This often results in the denial of their capacity and their legal right, as individuals, to claim "human security." Such deprivation of institutional protection and societal services consequentially leads to the erosion of their "personal security," ultimately their very life and existence. In this chapter, "security," unless specified, refers to "human security," deprivation of which ultimately threatens the "personal security" of FODWs and their families.

It is important to note that immigration, nationality, and labor-related legislation and policies in most countries today are unlikely to be explicitly discriminatory against women. In their written form, they appear to be value-neutral. However, as mentioned, when actually implemented they became gendered in the sense that women are regarded as individuals who do not work or reside on their own account. Their entry statuses are often based on that of male members of the family, preventing women from accepting a waged job or remaining in the country if they get divorced or lose their male partner. In reality, as previous research has demonstrated, FODWs are placed under the triple burdens of gender, ethnicity/race, and occupation (Anderson, 2000, pp. 1-8). Thus, neutral-sounding legislation and policies play a key role in rendering FODWs' "insecurity" invisible, leaving the triple burdens of FODWs intact.

Worse, as the following section demonstrates, FODWs today face not only national legislation and policies that implicitly exploit and discriminate against them in comparison to male migrants, but also regional and global regimes. In combination, they remove the plights and exploitation of FODWs from public view. This triple layer of national, regional, and global regimes, which enhances the "insecurity" of FODWs, is the main characteristic of today's migration control mechanism. It is therefore vital to shed light on this complex multi-layered mechanism by unwrapping it, layer by layer, and examining how each layer works in combination with the others to prevent FODWs from pursuing their "security."

\subsubsection{What does security studies learn about the "insecurity" of FODWs from migration and gender studies?}

Towards and since the end of the Cold War, according to Krause and Williams (1996, p. 229), three main factors have determined the course 
of development in the field of security studies: first, dissatisfaction among some scholars of security studies regarding the emphasis on states and the traditional military-centric approach of neo-realists; second, an urgent need to respond to the challenges arising from a post-Cold War security order; and third, a strong desire for the security studies discipline to become more relevant to contemporary concerns. Broadly, Krause and Williams point out three directions in which the so-called "new thinking on security" debate is heading (Krause \& Williams, 1996, pp. 229-230). The first approach aims to broaden the scope of security studies with the purpose of including non-military issues under the concept of "security." The second trend is to deepen the agenda of security studies by flexibly adjusting the level of analysis from that of individual or human security to that of international or global security. The third group maintains the state-centric approach, but focuses its analysis on diversified forms of inter-state security cooperation, such as common, cooperative, collective, and comprehensive cooperation (Krause \& Williams, 1996, p. 230). The traditional approach in the field sees states, groups, or individuals as givens, and treats threats external to these givens in the search for solutions to remove such threats. In contrast, the first and second approaches mentioned above focus on the process through which threats against an individual or group are constituted as "social facts" (Krause \& Williams, 1996, pp. 242-243). Their interest therefore lies in who-a government, business enterprise, or charismatic person-defines "security" for particular issues-economic well-being, military build-up, or environmental degradation-and in the process, under what conditions do they effectively provide it (Krause \& Williams, 1996, pp. 242-243).

Among the scholars within this "new thinking on security," Buzan and those who contributed to his work (1998) engage in "the most thorough and continuous exploration of the significance and implications of a widening security agenda for security studies" (Huysmans, 1998, p. 480). Nonetheless, even their efforts are criticized for failing to pay attention to the concept of "security" on the basis of gender. ${ }^{11}$ This lack of attention, Hansen (2000) insists, results from one of the two main shortcomings of security studies, namely "security as silence." ${ }^{12}$ According to Hansen, "security as silence" occurs in situations where the potential subject of security is forced to either remain silent or likely face even greater "insecurity" if the particular situation should receive attention. FODWs fit well into this category. As "women," they face enormous pressures to tolerate lesser "security," whether in their home country or receiving countries. In addition, as "overseas workers," their entry 
status often depends entirely on their employers, thus depriving them of any chance of challenging their bosses. In particular, for "irregular" or "illegal" female workers, the only remaining option is to remain silent in spite of their constant "insecurity." Regardless of whether remaining silent is instigated by force or by one's own will, unless the resulting "insecurity" surfaces, the phenomenon will never become a subject of security studies. Consequently, the "insecurity" of FODWs has remained under-studied until very recently. Those researchers who try to introduce gender perspectives into security studies argue that the concept of "security" needs to be redefined in a way that reflects the economic, political, or social conditions surrounding a particular individual or group. ${ }^{13}$ Whether one feels "secure" or "insecure" depends on one's position. Thus, what should really be examined are the economic, political, and social structures within which "security" and "insecurity" are constructed (Tickner, 1997, p. 624).

In the 1990s, migration studies researchers began to learn from gender studies, thus becoming exposed to a new understanding of "security." Since the late 1980s, they had already begun rectifying the stereotype of a migrant being male and single. Yet, their efforts fall short of transforming their analytical approach wholeheartedly; female migrants are still often simply added alongside their male counterparts as further issues of concern. Some critics thus described this new approach in migration studies as "adding women and stirring" (Curran et al., 2006, p. 209). In the early 1990s, academic interest within the field further shifted to network formation in a transnational setting, especially on the basis of, and with an emphasis on, race, ethnicity, and nationality. Meanwhile, those academics sympathetic and devoted to gender perspectives became concerned that what they had learned in the late 1980s might once again be forgotten in the new agenda. This time, in paying attention to gender issues in the context of transnational settings, they attempt to present analytical frameworks under which one does not merely "add women and stir," but that rather bring "gender" as a relational concept into a holistic perspective. This new analytical framework focuses on the way in which gender relationships are constructed beyond national borders. Henceforth, the treatment and identity of FODWs also becomes subject to transnationally constructed gender relationships (Donato et al., 2006, pp. 3-26).

Among various scholarly works that aim to bring gender into migration studies, that of Pessar and Mahler presents an analytical framework based on "gender geographies of power (GGP)" (Pessar \& Mahler, 2003, pp. 812-846). This deserves special attention. The GGP framework has 
four key concepts as its main constitutive pillars. These are "geographical scales," "social location," "power geometry," and "imagination." First, according to Pessar and Mahler, gender-a relational concept-operates within "geographical scales" that comprise multiple spatial and social scales across transnational spaces. At the same time, gender ideologies and relations are continuously reaffirmed and reconfigured within each constituent "geographical scale." "Social location," as the second component of this analytical framework, refers to people's positions within interconnected power hierarchies, which are created through various socially stratifying factors such as history, politics, economics, geography, and kinship. Since the hierarchies of each factor operate at various levels and affect the "social location" of individuals or groups, Pessar and Mahler emphasize that social location is always fluid and not fixed. Certain advantages and disadvantages are conferred according to one's "social location." Furthermore, "social location" determines the types and degrees of agency one can exercise. Pessar and Mahler call this "power geometry," which is the third component of their framework. The fourth component is "imagination." In examining agency, they emphasize that it not only implies people's ability to influence others and their surroundings, but also their cognitive power to initiate change. Suppose that two people are in the same "social location." One might simply be buried, whereas the other might intend to fight back thanks to "imagination."

Focusing on "power geometry" makes us aware that it is not only crucial how transnational "geographical scales" are formed; it is also who and what controls their formation that plays the key role in understanding the "security" and "insecurity" of today's FODWs. This general understanding draws our attention to multiple-layered migration regimes, which are touched on in the next section. Such layers of legality reflect the intentions of the powerful within today's "geographical scales." Given that various regimes intend to keep FODWs in their current "social position"—invisible—it may still be possible for FODWs themselves to transform their "power geometry" through "imagination." Taking "imagination" into consideration, the GGP framework suggests that not all FODWs should remain powerless, exploited, and controlled by employers and governments in their host and home countries. It recognizes that their "social location" can shift. "Power geometry" is malleable, and some FODWs could someday fulfill the roles of initiators, refiners, and transformers. To frustrate such challenges from FODWs, however, powerful players-national governments being the main players in this case-continue to strengthen confining mechanisms, among 
which migration regimes comprise the most explicit and concrete form. They play an important role in depriving FODWs of "imagination" and maintaining the current "power geometry." In building multiple-layered migration regimes at the global, regional, and local levels, national governments of both developed and developing countries aim to control the transnational "geographical scales" in which they are predominant.

\subsection{National, regional, and global regimes surrounding FODWs}

\subsubsection{National regimes}

Currently, governments in Western developed countries adopt citizenship- and immigration-related legislation and policies that reflect an "anti-immigrant, pro-immigration" nature. ${ }^{14}$ The purposes of these types of policies in relation to FODWs are two-fold. First, to keep them marginalized in the society, they force FODWs to accept only certain types of occupation and working conditions. Second, they enable the host government to increase the volume of incoming FODWs for the purpose of upholding the "security" of its nationals in exchange for the FODWs' "insecurity." For example, the work permit system not only distinguishes between immigrants with legal or illegal entry status, but also ties the former to certain jobs and certain working conditions. In the view of governments in developed countries, what they need is not "immigrants in general" but "those who fulfill a certain job." Thus the main aim of currently implemented immigration regimes is to link immigrants to precisely those jobs that nationals neither wish to have nor dare to fill. In this way, host governments can enjoy the benefits of introducing foreign workers who will work for the nation's citizens and raise their level of "security" at very little cost.

Taking the British case as an example, British legislation and policies in the migration-related field no longer include explicitly discriminatory terms and provisions against female migrants. On further scrutiny, however, some legislation and policies are applied in a way that might be disadvantageous to women. Three areas where discriminatory practices against immigrant women may abound are the right of entry, residence, and employment; of family reunion; and of family formation in the form of marriage. First, given that a woman enters the country as the "spouse" or "child" of a legal male entrant, her right to enter and reside subsequently depends on the right of her husband or father. Under the status of "spouse" or "child," such women are consequently prevented from accepting paid work. Suppose a woman enters a country 
as a legally independent immigrant. In this case, a typical job for her, such as domestic worker or carer, tends to be less likely than other jobs to confer her with permanent residency. As a result, migrant women are subject to a higher risk than their male counterparts with regard to losing their legal entry status and being deported, for example in the case of divorce for married women or unemployment for independent migrant women. In 1979, the British government abolished the visa category for overseas domestic workers (ODWs). Instead, they created a special category to allow the wealthy to bring their domestic workers with them (Bhabha, 1994, pp. 173-184; Anderson, 2000, pp. 86-107). This category, however, was specifically linked to wealthy entrants, and their accompanying domestic workers were not allowed to change employer lest their entry status be stripped. Until 1998, when immigration regulations regarding ODWs were amended, such workers had to endure severe working conditions and even violence from their employer for fear of being deprived of their legal status and thus being deported.

The second set of barriers experienced by immigrant women arises in connection to family reunion. The fundamental right to family reunion is enshrined in the European Convention of Human Rights, for example. However, it is usually provisional and governed by a set of regulations. The required access to adequate accommodation and the necessary proof of sole responsibility for childrearing are two examples that often work against women in Britain. With their low wages, FODWs find it difficult to secure their own accommodation to fulfill the requirements of immigration rules. Worse, most FODWs often live with their employers; thus, they have no option of bringing their children even if they wished to. A thornier regulation that implicitly discriminates more against women than the housing one does is that of "sole responsibility," a regulation introduced in 1968. Under the 1968 Commonwealth Immigrants Act, immigration rules allowed immigrants to bring their children only if they as parents residing in Britain had "sole responsibility" for the child's upbringing (Home Office, 2005, Chapter 14.5). These provisions, although unintended by the then government, worked against many immigrant women from Caribbean countries. Some researchers suggest that immigration officers either consciously or subconsciously believe in the male breadwinning model, and thus think that the male member of the family (father or grandfather in this case) determines where the family should be located (Bhabha, 1994, pp. 31-39). It is therefore difficult for mothers to bring their children to Britain if their fathers or grandfathers, unemployed as they may be, reside in their home countries. 
The last case of implicit disadvantage for migrant women relates to international marriage. The British government introduced the "primary purpose rule" in the 1980s. Until this rule was abolished in 1997, those who wished to bring spouses or fiancé(e)s had to prove the genuineness of the marriage and that it was the primary reason for coming to Britain. Although this rule itself did not include sexually discriminatory phrases or conditions, its application tended to be harsher towards women. A general stereotype was that male immigrants were more of a threat to the labor market than their female counterparts. In consequence, when immigrant women applied to the Home Office to invite their husbands or fiancés, they were investigated more thoroughly than immigrant men were. It was also the case that British immigration rules in relation to marriage were based on the prevalent understanding of marriage under British law. Consequently, women in polygamous marriages were not considered as wives, and second wives were prevented from entering Britain as spouses. Also, so-called child wives under 16 years of age were not admitted as either a spouse or fiancée.

Regardless of the long history of female migration, female migrants even today remain invisible with regard to policy making and research. As pointed out in the previous section, governments select certain types of migrants, and in receiving them, they attempt to maintain the current "power geometry." Inflows of live-in overseas domestic workers may reduce the burdens of domestic chores and appear beneficial to female nationals with waged jobs. In reality, reliance on FODWs keeps intact and reinforces traditional stereotypes of "women at home doing housework" and "women taking care of the elderly and childrearing at home." All in all, this may actually prolong the unfair treatment of women. In sum, "anti-immigrant, pro-immigration policies" not only determine the "social location" of female migrants but also that of female nationals at the same time. Women, whether nationals or immigrants, are kept in a weaker "social location" and their agency still depends on male members of the family. In general, only a few lucky women take up paying jobs, forcing other unlucky women to take over domestic chores, doing so under the conditions set by the current "power geometry" of male dominance and female subjugation.

\subsubsection{Regional and global regimes}

Traditionally, national governments have claimed the exclusive authority to control who enters, stays in, and leaves their territory. Yet, national governments are now aware that they need to act together to tighten control over the international movement of people. Thus, they have 
established a form of inter-state cooperation to deal with the growing volume. In the field of migration control, therefore, both regional and global levels of control mechanisms are added, complementing national policy instruments designed to uncover undocumented or overstayed foreign migrants and deter asylum-seekers. It is true that national governments are also delegating policy implementation to municipal and local sectors, conferring upon them, for example, the competence and authority to check suspicious cases. ${ }^{15}$ Nevertheless, such sectors are subject to their national governments and do not generally take their own policy initiatives. This chapter thus concentrates on the development of regional and global migration control policies, focusing on those of the European Union (EU), and on global cooperation in the form of international conventions.

It may be true that regional and global institutions such as the EU and the United Nations (UN) exert only an indirect and non-compulsory influence on national policies. Nevertheless, they may play an important role in advancing some kind of agenda and changing our mental frame of perception. The idea of universal human rights is the prime example, and has been greatly promoted since the end of the Second World War by international and regional organizations and through various international conventions (Donnelly, 1986, pp. 599-642). Human rights activists and groups, in the face of domestic deadlocks, bypass national governments. They seek support from international organizations to have them exert pressure from abroad to change national policies. Through the "boomerang effect" (Keck \& Sikkink, 1998), they wish to ensure that national governments admit cases of human rights violation and rectify them. This certainly also applies to the subject of this chapter. When the maltreatment and invisibility of FODWs come to light, regional and global institutions may be able to affect national policies. Possibly, the current "power geometry" may shift through these regional and global regimes, and FODWs might finally be able to speak up and improve their "security."

Recently, the UN and regional organizations such as the EU have become extremely active in promoting multinational cooperation to combat the trafficking of migrants (United Nations General Assembly [UNGA], 2000a, b). Although promoters of multinational cooperation claim that remedies for victims of trafficking are the prime purpose, the actual practice of existing cooperation appears to concentrate on controlling and regulating the international movement of people. Actual help for the victims is supposed to be left to national governments, but concrete actions seem to be slow to evolve. Contrary to the high hopes 
of human rights academics and activists, neither regional nor global regimes in the field of migration are aiming to shift the "power geometry" in favor of migrants. They are more likely to deny the potential agency of migrants who have already been rendered powerless, and to uphold the very "power geometry" that works against them. Some academics even suggest that national governments deliberately advance regional and global regimes with the intention of avoiding the national judiciary and furthering control over migrants (Guiraudon \& Lahav, 2000, pp. 163-195). In a sense, the establishment of regional and global regimes diversifies the means of national government, and expands the merits of the existing "power geometry." Furthermore, the levels of control mechanisms interactively strengthen each other.

If we look at the actual provisions of international conventions, we find that the term "gender" appears frequently within them. Relevant international organizations, such as the UN, have for some time actively promoted awareness of "gender-related" issues. After nearly 20 years' preparation, the UN finally adopted the International Convention on the Protection of the Rights of All Migrant Workers and Members of their Families (ICMW) in 1990. As the "first comprehensive universal codification of migrants' rights" (Cholewinski, 1997, p. 199), a migrant worker is defined in Article 2(1) as "a person who is to be engaged, is engaged, or has been engaged in a remunerated activity in a State of which he or she is not a national." This definition of migrant workers is considered the most comprehensive in any international instrument concerning migrants, and is thus praised in itself as a "major accomplishment" (Hune, 1987, pp. 123-124). Obviously, migrant women form part of the category of "migrant workers" and should be protected as such. They are also supposed to receive protection as members of migrants' families (Article 1). Specifically, Article 1 declares that the ICMW applies to all migrant workers and their families "without distinction of any kind," such as on the basis of sex. Article 7 also prohibits discrimination on the grounds of sex with respect to the rights provided for in the ICMW. To clarify the intent of sexual equality, the drafters of the convention decided to use the terms "he or she" and "his or her" instead of "he" and "his" towards the end of the preparatory process (Hune, 1991). They could not have made it clearer that all the convention's provisions are applicable to both migrant men and women.

Migrant workers are, according to the convention, to be treated equally to nationals with regard to economic, social, and cultural rights. For example, employment conditions (Article 25), social security (Article 27), emergency medical care (Article 28), and access to education 
(Article 30) are specifically mentioned as areas where equality should be guaranteed. Furthermore, Articles 26 and 40 provide migrant workers with the right not only to partake in trade union activities, but also to "form associations and trade unions in the State of employment." The right to education is also widely conferred upon migrant workers, as seen in Article 43, for example. It grants migrant workers and nationals equal access to vocational guidance, training, and retraining facilities. Migrant women who had been treated as invisible even in their home countries might be able to make use of the opportunities provided by the convention to improve their "social location."

Even as a member of a migrant's family, female migrants can receive access to vocational guidance and training under Article 45, although the extent of access is limited in comparison to that stipulated in Article 43. In addition, the convention provides the possibility for migrant women who have entered a country as a dependent or spouse to remain and reside there even after the death of a migrant worker or the dissolution of their marriage (Article 50). To save family members in the case of a migrant's death or divorce, the provision imposed the obligation on states to take into account the length of their stay and authorize them to remain and even work. Even though it does not grant them an absolute right to remain in the country of employment, this special consideration to family members was a welcome addition for migrant women whose residential status was conditionally based on the status of their husbands or fathers.

Despite these provisions, the ICMW has received considerable criticism for not paying sufficient attention to migrant women since its enactment (Hune, 1991, pp. 800-815). The biggest criticism arises from the fact that the convention fails to go beyond the "add women and stir" approach. As Hune (1991, pp. 812-813) suggests, the ICMW drafters did not consider that the concept of "labor" may not mean the same to women as to men. As mentioned earlier, a number of migrant women are employed in the care and housekeeping fields. These fields have for a long time been considered as "women's fields," in which they are supposed to excel by nature. As a result, jobs related to domestic chores, childrearing, and elderly care, for example, are often paid very little or next to nothing. To some people, these jobs do not qualify as "waged labor," as they do not require any special skills or talent, since women are supposed to be born with such skills. The ICMW simply aims for sexual equality, but does not intend to tackle these implicit assumptions or the notion that "female-type work" is inferior to "male-type work." In addition, the convention does not consider that female migrants have 
to play the role of primary caregiver for children and family members, spending more time than their male partners at home to perform household chores. Given that equal access to "labor" between nationals and migrants is guaranteed, female migrants, in contrast to males, need further public support from their host countries before they can accept employment. Without waged employment, migrant women may continue to rely on their spouses and remain invisible in the host society. As previously pointed out, seemingly neutral terms such as "labor" and "laborer" are often defined in a way that might disadvantage women, and thus require redefinition to change the existing "power geometry." Ultimately, the ICMW does not aim for the fundamental transformation of the "power geometry," but rather for the alleviation of the plights of migrants within given circumstances.

At the level of regional regimes such as the $\mathrm{EU}$, issues relating to migrant women are also handled with the "add women and stir" approach. The frequent appearance of the term "gender" in EU publications might not yet have resulted in the improvement of the "social location" of women in general. EU social policies have gone to great lengths to establish equality between women and men, especially in terms of access to labor markets (Ackers, 1998, p. 2). Not only policy makers but also academics are seeking the best way to achieve equal treatment between the sexes at the EU level. A voluminous amount of research has been conducted on gender equality in labor markets for quite some time. ${ }^{16}$ As mentioned with regard to the global regime, while current EU policies may improve the "social location" of EU working women in employment, they are not intended to challenge the current "power geometry" of FODWs. They simply allow EU women with a job to be treated in the same way as EU men, as long as the traditional "white male breadwinning model of family relations" remains intact. In other words, according to Ackers, all residents of the EU are classified into several categories on the basis of citizenship, gender, and access to employment, and are prioritized according to a combination of these three factors (Ackers, 1998, p. 40). Within the hierarchy of people legally resident in the national territory, those males who contribute to the labor market and hold citizenship are ranked first. Next are female spouses with citizenship, as they are acting as women are "supposed to"-that is, being supportive of male citizens. Illegal migrants aside, the remainder of the pecking order is as follows: working female citizenship holders, citizenship holders not active in the labor market-single mothers and the elderly, for example-employed legal male migrants, and a small number of 
female migrants holding skilled jobs. Unfortunately, FODWs are still at the very bottom (Ackers, 1998, p. 40).

Finally, seemingly neutral concepts and categories such as "labor," "laborers," and "waged labor" have all been defined in a male-dominant world. Thus, they intentionally or unintentionally tend to lower women's "social location." Peterson declares that regimes based on male experience and male understanding cannot really account for women (1996, pp. 11-28). Accordingly, three options are suggested: "either females cannot be added (they are marginalized), or they must become 'like men' (they are masculinized), or they are included, and the meaning of the category is transformed to include femaleness." (Peterson, 1996, p. 17, emphasis in original). So far, the current regional and global regimes include women by forcing them to "masculinize" themselves for fear of being "marginalized." It is obvious that traditional concepts, categories, and stereotypes need to be transformed to include femaleness if we are to aim to fundamentally challenge the "power geometry" on women's behalf and to improve their "social location." Currently, regional and global regimes might work favorably for some women who become "masculinized." To other women, the vast majority perhaps, they merely complement national regimes that make women accept more "insecurity" than men. For FODWs, today's multiple-layered regimesnational, regional, and global-form an even more starkly oppressive environment than before.

\subsection{Conclusion}

This chapter has attempted to make three points. First, today's FODWs are not singularly glued to a certain "social location" by national regimes. Rather, they are triply fixed in their social and legal cage by the two additional layers of regional and global regimes. At a superficial glance, the emergent regional and global regimes in the field of migration offer a glimmer of hope in that they seem concerned with the plights of FODWs and appear to offer a remedy for them. In reality, they are favorable only to a small group of women who are willing to accept the current "power geometry." FODWs remain, as always, powerless and invisible. Worse, their "insecurity" is triply fixed. Second, emergent regional and global regimes do not aim to challenge the current "power geometry" and FODWs' resulting "social location" at the very bottom in any host country. Regional and global regimes may only indirectly influence national governments and policy makers, provided their "boomerang effect" is felt. Yet, today's regional and global 
regimes relevant to migration are established to protect "laborers" and "migrants" as they are currently understood. By accepting these concepts, these regimes, albeit inadvertently, may be supporting, reinforcing, and cementing the current "power geometry."

Third, as migrant women move across national borders, so too does their "insecurity." Unfortunately, space limitations restrict this chapter from providing further examination of the above cases in Britain or additional examples outside of Europe. We nonetheless find in today's world the prevalence of "insecurity" that crosses borders to the families of FODWs back home in return for the "security" of nationals in their country of employment. As mentioned earlier, the benefits of "global householding" are reaped by people in developed countries at the expense of the damage of "global de-householding," which is shouldered by those in developing countries. Of course, the perception of the phenomenon as "global householding" or "global de-householding" differs depending on timing and the focus of analysis. Yet, by presenting the two concepts together, we can highlight a lopsided relationship between FODWs and their families back home vis-à-vis their employers in the host countries. Once aware of the zero-sum elements of "global householding" and "global de-householding," we can take a further step to reveal how these are currently consolidated and even strengthened. Emerging regional and global regimes neither guarantee "security" for FODWs nor prevent "insecurity" from being transferred to their own families, let alone saving them. Worse, most FODWs are from developing countries where social welfare systems are barely existent. While the family members left behind-especially the elderly and infants-may benefit economically by receiving money, they certainly lose out psychologically.

The previous section cited Peterson, who stressed the need to transform traditional concepts and categories, as they were formed through male experience and thus oblivious to the experience of women. Otherwise, the current "power geometry" surrounding FODWs will remain unchanged. Recently, some academics have paid attention to networking and the mutual assistance in which FODWs are actively engaged, claiming that they constitute burgeoning "political activities" and portraying them as signs of change (Kofman et al., 2000, pp. 163-191). In line with this argument, Kofman and others, for example, dispute conventional understanding with regard to the political rights of migrants. They insist that while FODWs might be devoid of voting rights, they are devoid of other types of political activities within the host society as well. Through community groups and networks, FODWs are in constant contact with each other and even with the 
host population. Taking a wider definition of "politics," Kofman and others try to perceive FODWs not as "objects of political discourse," but as "participating subjects" (p. 163). Since most FODWs in their home countries were afforded limited access to any kind of political activity, they may be more liberated in their countries of employment, thus finding themselves in a much stronger "social location." To some academics, therefore, FODWs might be accredited with the "power to effect change" (Hardy-Fanta, 1993, p. 30). Undoubtedly, FODWs are not always submissive, invisible, and passive objects of exploitation and oppression. Legal exclusion from the formal political process without the right to vote in a way encourages FODWs to become more active in forming associations and networks in their daily lives.

Pessar and Mahler's analytical framework-"gender geographies of power"-introduced and applied in this chapter, presents "imagination" as one of the four main components. Considering people in similar "social positions," some remain subdued while others take the initiative to challenge the system. The root of these different reactions lies in "imagination." Therefore, FODWs' networks and community campaigns might some day provide a strong initiator for change and result in a more tangible challenge to the current "power geometry." Even so, one of the three main arguments of this chapter was the emergence of multiple-layered regimes that threaten the "security" of FODWs. Whatever activities FODWs may be involved in within their country of employment and residence, such activities need to go beyond national borders before they can ever lead to a shift in "power geometry" in a transnational arena. There is no doubt that we should encourage the burgeoning political activities of FODWs, but at the same time, we should not expect too much from them. Ultimately, challenges to and alteration of the "power geometry" should come from those with power. Only they can build counter-regimes of transnational "geographical scales" and transform the "power geometry" in favor of the powerless. Only with their concession and willingness can we establish a truly multicultural space in which differences in power, gender, wealth, and so on are intensively negotiated, and even reconciled.

\section{Notes}

Professor, Faculty of Policy Studies, Kansai University. This chapter is based on a presentation given at an international conference--"Global Migration and the Household in East Asia"-in Seoul, on 2-3 February, 2007. The author is grateful for all the comments from the floor. 
1. Persons who look after children on a contract basis are referred to in various ways, for example as a "nanny," "au pair," "maid," and "child-minder." The definitions of these terms may differ according to the country and era. In Britain, for example, "au pair" is a legal immigration status, denoting a person who matches the required conditions of age, country of origin, and employment details. "Child-minders" are required to register themselves in Britain, while "nannies" and "maids" lack any form of legal definition. "Nannies" usually concentrate on childrearing at the employer's house, whereas "maids" are responsible for all kinds of housework chores as well.

2. Anderson (2000, p. 7) emphasizes the role of a "female" employer who often hires female overseas domestic workers (FODWs) under oppressive working conditions.

3. The ILO convention concerning decent work for domestic workers (no. 189) came into entry in 2013 in order to combat deplorable working conditions, labor exploitation, and abuses of human rights. Although the number of domestic workers is steadily increasing all over the world, only 12 countries so far have ratified this convention.

4. Douglass (2006). Professor Michael Douglass' research program at Hawaii University introduces the term "global householding." The term "household" includes members based on fictive family relationships, such as nannies, who take the childrearing role over from birth parents, and live-in overseas carers, who look after elderly members of a family. In contrast, the term "family" is usually restricted to biological members. Nowadays, many "families" in both developed and developing countries may have members working or residing abroad. As the volume of movement of people beyond borders increases, so does the number of families who, for their livelihoods, depend on money sent from abroad by family members or who hire workers from abroad to perform their household chores. In sum, it is more appropriate to use the term "household" or even "householding" than "family" to describe how people in the globalized world live and conduct their daily lives.

5. "Security" can mean both "human security," which is protected by social institutions, and "personal security," which implies the maintenance of one's life. In the case of FODWs, the threat to their "human security" by global, regional, and national regimes tends also to threaten their "personal security," leading them into conditions of "insecurity."

6. There does not yet exist an authoritative definition for "gender." The author follows Pessar and Mahler and defines "gender" as a "process, as one of several ways humans create and perpetuate social differences." Pessar and Mahler (2003, p. 813) also consider "gender" as a structure "embedded in institutions." The author agrees with this view, seeing "gender" as part of a complex web of institutionalized social relationships that determines one's power within a society.

7. For the case of Britain, see Bhabha and Shutter (1994) for example.

8. Castles and Miller (2009, pp. 8-9). Five other characteristics are "globalization," "differentiation," "acceleration," "politicization," and "proliferation of migration transition."

9. Kofman et al. (2000). Their work is one of the recent pieces of academic research to have systematically surveyed the plights and treatment of FODWs. 
10. Chang (2000) emphasizes the impact of SAPs on pushing female laborers in developing countries to developed countries to seek higher paid jobs.

11. Hansen (2000), Steans (2006, pp. 63-77), Tickner (1997, pp. 611-32, 2001, pp. 36-64). These scholars emphasize the importance of combining gender and security studies in general.

12. Hansen (2000, pp. 287, 294-9). The other shortcoming, according to Hansen, is what she terms "subsuming security." She argues that gender-based insecurity tends to be treated as an aspect of national or religious security, and that female victims are not regarded as a "referent object." Unless recognized as a "referent object," they cannot become the subject of security studies.

13. Tickner (2001, pp. 36-64) provides a thorough survey on the way security studies is developing by learning from feminist perspectives.

14. Chang (2000, pp. 30-31) points out the differences between pro-immigration policies and pro-immigrant policies. According to Chang, the former simply encourages the inflow of immigration, which does not necessarily mean that it is friendly toward immigrants. It is therefore possible to have a proimmigration and anti-immigrant policy at the same time.

15. Guiraudon (2000, pp. 249-69). Since the 1980s, quite a few developed countries in Western Europe have begun to involve local and municipal governments in migration control mechanisms. Concentrating on the case of the $\mathrm{EU}$, Guiraudon, for example, has worked on the vertical diversification of migration control mechanisms, both upward to an international level and downward to a local level.

16. See, for example, Gregory, Sales, and Hegewisch (1999) and Council of Europe (1996). These works are typical examples of research conducted in the 1990s.

\section{References}

Ackers, L. (1998). Shifting spaces: women, citizenship and migration within the European Union. Cambridge: Polity Press.

Anderson, B. (2000). Doing the dirty work? The global politics of domestic labor. London: Zed Books.

Bhabha, J. \& Shutter, S. (1994). Women's movement: Women under immigration and nationality and refugee law. London: Trentham Books.

Buzan, B. (1991). People, states and fear. Hemel Hempstead: Harvester Wheatsheaf.

Buzan, B., Wæver, O., \& de Wilde, J. (1998). Security: A new framework for analysis. Boulder: Lynne Rienner.

Castles, S., \& Miller, M. J. (2009). The age of migration: International population movements in the modern world (4th edn). London: Macmillan.

Chang, G. (2000). Disposable domestics: Immigrant women workers in the global economy. Cambridge: South End Press.

Cholewinski, R. (1997). Migrant workers in international human rights law: Their protection in countries of employment. Oxford: Clarendon Press.

Connell, J. (Ed.) (2008). The international migration of health workers. London: Routledge.

Council of Europe (1996). Joint specialist group on migration, cultural diversity and equality between women and men, final report of activities (EG-MG, 2 rev.). 
Retrieved form http://www.coe.int/t/dghl/standardsetting/equality/03themes/ gender-equality/EG-MG(1996)2_en.pdf.

Curran, S., Shafer, S., Donato, K., \& Garip, F. (2006). Mapping gender and migration in sociological scholarship: Is it segregation or integration? International Migration Review, 40, 199-223.

Donato, K., Gabaccia, D., Holdaway, J., Manalansan, M., \& Pessar, P. (2006). A glass half full? gender in migration studies. International Migration Review, 40, 3-26.

Donnelly, J. (1986). International human rights: a regime analysis. International Organisation, 40(3), 599-642.

Douglass, M. (2006). Global householding in Pacific Asia. International Development Planning Review, 28(4), 421-45.

Ehrenreich, B., \& Hochschild, A. R. (2002). Global women: nannies, maids, and sex workers in the new economy. New York: Henry Holt and Company.

Enloe, C. (2000). Banana, beaches and bases: Making feminist sense of international politics (2nd edn). Berkley: University of California Press.

Gregory, J., Sales, R., \& Hegewisch, A. (1999). Women, work and equality: The challenge of equal pay in a deregulated market. London: Macmillan.

Gregson, N. \& Lowe, M. (1994). Servicing the middle classes: Class, gender and waged domestic labour in contemporary Britain. London: Routledge.

Guiraudon, V. (2000). European integration and migration policy: Vertical policy-making as venue shopping. Journal of Common Market Studies, 38(2), 249-269.

Guiraudon, V. \& Lahav, G. (2000). A reappraisal of the state sovereignty debate: The case of migration control, Comparative Political Studies, 33(2), 163-195.

Hansen, L. (2000). The little mermaid's silent security dilemma and the absence of gender in the Copenhagen School. Millennium, 29(2), 285-306.

Hardy-Fanta, C. (1993). Latina politics-Latino politics. Philadelphia: Temple University Press.

Hatsuse, R. (2003). "Nihgen no anzenhosho" ron no houkousei [Directions for the studies of "human security"], Gendaishakai kenkyu [Contemporary Research], 4/5, 81-95.

Home Office. (2005). UK visas diplomatic service procedures entry clearance vol. 1 general instructions (Chapter 14.5).

Hune, S. (1987). Drafting an international convention on the protection of the rights of all migrant workers and their families. International Migration Review, $21,123-127$.

Hune, S. (1991). Migrant women in the context of the international convention on the protection of the rights of all migrant workers and members of their families. International Migration Review, 25, 800-815.

Huysmans, J. (1998). Revisiting Copenhagen: Or, on the creative development of a security studies agenda in Europe. European Journal of International Relations, 4, 479-505.

Keck, M. E. \& Sikkink, K. (1998). Activists beyond borders. Ithaca: Cornell University Press.

Kingma, M. (2006). Nurses on the move: Migration and the global health care economy. London: ILR Press.

Kofman, E., Phizacklea, A., Raghuram, P., \& Sales, R. (2000). Gender and international migration in Europe. London: Routledge. 
Krause, K. \& Williams, M. C. (1996). Broadening the agenda of security studies: politics and methods, Mershon International Studies Review, 40, 229-254.

Parreñas, R. S. (2005). Children of global migration: Transnational families and gendered woes. Stanford: Stanford University Press.

Pessar, P. R. \& Mahler, S. J. (2003). Transnational migration: Bringing gender. International Migration Review, 37, 812-846.

Peterson, V. S. (1996). Shifting ground(s): Epistemological and territorial remapping in the context of globalization(s), In E. Kofman, \& G. Young (Eds), Globalization: theory and practice (pp. 11-28). New York: Pinter.

Smith, J., Wallerstein, I., \& Evers, H. D. (1984). Households and the world-economy. London: Sage Publications.

Steans, J. (2006). Gender and international relations: Issues, debates and future directions (2nd edn). Cambridge: Polity.

Tickner, J. A. (1997). You just don't understand: troubled engagements between feminists and IR theorists. International Studies Quarterly, 41(4), 611-632.

Tickner, J. A. (2001). Gendering world politics. New York: Columbia Univ. Press.

United Nations Development Program (1994). Human development report 1994: New dimensions of human security. New York: Oxford University Press.

United Nations General Assembly (2000a). Protocol against the smuggling of migrants by land, sea and air, supplementing the United Nations Convention against transnational crime. Treaty Series. (Vol. 2241, p. 507, Doc. A/55/383). New York: United Nations.

United National General Assembly (2000b). Protocol to prevent, suppress and punish trafficking in persons, especially women and children, supplementing the United Nations Convention against transnational organized crime. Treaty Series. (Vol. 2237, p. 319, Doc. A/55/383). New York: United Nations.

Except where otherwise noted, this work is licensed under a Creative Commons Attribution 3.0 Unported License. To view a copy of this license, visit http://creativecommons.org/licenses/by/3.0/ 